Student Ethics in Engineering: A Comparison of Ethics Survey Results from Undergraduate Engineering Students at Three Different Engineering Programs and Institutions

Dr. Jessica A Kuczenski, College of San Mateo / San Francisco State University 


\title{
Student Ethics in Engineering: A Comparison of Ethics Survey Results from Undergraduate Engineering Students at Three Different Engineering Programs and Institutions
}

\begin{abstract}
The objective for this study is to compare the attitudes and practices regarding ethics of undergraduate engineering students from three different institutions, and also against those reflected by national surveys. For this study, a survey was written and delivered to undergraduate engineering students at three different institutions regarding their perception of ethics at school and in the workplace, along with specific ethical behaviors during their college careers. The survey was conducted anonymously; thus, the survey data is only available en masse for each school population polled. Results from this study found that high numbers of students, nearly $50 \%$ to over $90 \%$, of students have done, considered and know others who have engaged in unethical behaviors, especially at school. Differences between the schools showed that students from Century College had the lowest values of unethical behaviors at school, but also had higher rates of unethical behaviors at work, likely due to a larger work experience than for the other students polled. Additionally, one specific ethical behavior with the highest percent of students admitted to was in the area of plagiarism (direct homework set copying), where students from Notre Dame and Century College both had higher rates (60\% and 39\%, respectively) than those from national surveys (23-27\%). Overall, we found that significant differences exist between the three institutions polled, both for school and workplace ethics, and that although specific ethical behaviors between Notre Dame and Century College were in general similar to those from national surveys, there were differences noted in the areas of exam cheating and plagiarism.
\end{abstract}

\section{Introduction}

Engineering is an important and learned profession. As members of this profession, engineers are required to adhere to the highest principles of ethical conduct as engineering is a profession with public purposes, including contributing to public safety and the environment. Thus, engineers must maintain standards of honest and conscientious practice as is crucial for maintaining human welfare.

Dishonest (unethical) behavior in the engineering workplace has been found to be linked to academically dishonest behavior in college. ${ }^{1-3}$ Unfortunately, academic dishonesty is widespread in the United States. ${ }^{4}$ Undergraduate engineering students have been reported to be some of the most likely to engage in academic dishonesty. ${ }^{5-7}$ Whether this is due to academic pressures, peer pressure or perceptions, faculty involvement, or other factors, engineering students have selfreported dishonest behavior in over $80 \%$ of students. ${ }^{4}$ Thus, academic dishonesty in engineering is particularly worrisome as significant consequences to society may result from this dishonesty.

Unfortunately, academically dishonest behavior by the students often leads to higher grades for the student. Not only is this an unfair representation of the students' knowledge and worth which misrepresents the student's institution, but also is an unfair assessment when used as a predictor of future success. ${ }^{8}$ While the causes for cheating are disparate, some of the reasons include the students feeling assignments are pointless and/or overwhelming, if the students lack respect for 
their teachers, or due to the widespread availability of materials through the web. One additional factor which may influence the unethical behaviors among students is their understanding of ethical behaviors and its importance as a professional responsibility. ${ }^{9}$ Thus, in this study, the primary objective is to poll students on their ethical behaviors both at school at in the workplace to understand how different institutions may view unethical behaviors and compare this data against national surveys.

\section{Procedure}

At each institution, a survey on student ethics was written and delivered to the students. The first institution chronologically was Rose-Hulman Institute of Technology (RHIT) and the survey given is available in Appendix A. This survey consisted of 8 ethical questions asking students about their perception of ethical behavior in the past several years, about unethical behavior by themselves and others both at school and in the workplace, about how ethically they would rate the behaviors of groups both at school and the workplace, and about how important ethical decision-making is in these areas. The survey was presented to the students after a lecture and discussion of ethics in the classroom. The survey was first introduced with its intentions, asked the students to respond anonymously, and assured the students the responses would only be taken en masse and could not affect their grades. The survey was given on paper and the instructor was not present while the survey was filled out. A student volunteer collected the surveys when students were finished, placed the responses in an envelope, and then retrieved the instructor. It is important to note that the student population at RHIT consists of traditional college students, entering college directly from their senior year of high school, and all students at RHIT intend to major in engineering. The survey at RHIT was given to 3 sections of Freshman Design (course ID EM103). A total of 38 students were polled with $100 \%$ return rate (section 11, $\mathrm{N}=14$; section 12, $\mathrm{N}=13$; section $13, \mathrm{~N}=11$ ). RHIT does have a Code of Ethics by which students are expected to abide.

At the second institution, the University of Notre Dame (UND), in addition to the 8 questions asked in the RHIT survey, the ethics survey was expanded to include questions for comparison to literature surveys, in particular a survey from the Center of Academic Integrity ${ }^{10}$ and a journal article from McCabe ${ }^{5}$. The ethics survey written and delivered to the students is available in Appendix B. At UND, a total of 126 students were polled: 68 second year, 55 third year, 3 fourth year students. These students were primarily chemical engineering (ChE) students (124 ChE, 2 computer science/engineering). The surveys taken in computer methods (CBE20258), process controls (CBE30338), and climate and energy (CBE40498) courses via Google Forms, with all students surveyed anonymously with only time stamp information collected. Students had the option of declining or accepting to be part of this study. Data analyzed was only from students accepting to be part of the survey and data was collected en masse. At UND all students pledge to uphold the academic honor code as a precondition for admission to the university.

The final institution, Century College (CC), had a very similar ethics survey to that of the UND survey. Some questions were altered to better fit the student population; this institution was geared for only first and second year engineering studies, and consequently does not have many of the laboratory courses that are found at bachelor degree granting institutions. The survey written and delivered at CC is available in Appendix C. A total of 91 students were surveyed at 
CC, all from the Introduction to Engineering (ENGR 1020) course. CC students are composed of a mix of traditional and non-traditional students from various backgrounds. Many students are in the first year of their engineering study, but many have other degrees or have pursued studies in other areas prior to joining the engineering department. At CC, students took the survey on paper after a lecture and discussion on engineering ethics, without the instructor present. Student responses were collected by a student volunteer and results recorded by a student worker not associated with the course. Only the collective results were then given to the instructor for analysis. CC has only a code of conduct; no honor code or code of ethics.

In all cases, the data collected from student responses were put into a spreadsheet and analyzed as a population. Descriptive statistics was used and calculated frequencies, means, standard deviations, and percentages for each population. All three institutions were compared for the first 8 questions of the survey, while only UND and $\mathrm{CC}$ were compared for the remaining final survey question.

The final survey question was then compared to literature sources from the Center for Academic Integrity ${ }^{10}(\mathrm{CAI})$ and a journal article from $\mathrm{McCabe}^{5}$. The CAI conducted a national survey on 'Student Engagement in Academic Dishonesty' in 2004-2005 with 15,664 sophomores, juniors and seniors from 18 institutions and 2,537 first-year students from 5 institutions responding. Tabulated results of this survey are reposted below in Table 1. Only the data from the non-first year students was actually included for comparison to our data as ND and CC student populations polled were not first-year or typical traditional first-year students.

Table 1: National Survey on Student Engagement in Academic Dishonesty from $\mathrm{CAI}^{10}$

\begin{tabular}{|c|c|c|}
\hline Specific Behavior & $\begin{array}{c}\% \text { of U.S. Students } \\
\text { Who Engaged in the } \\
\text { Behavior at Least Once } \\
\text { during their Past Year } \\
\text { in College }(15,664 \\
\text { sophomores, juniors } \\
\text { and seniors from } 18 \\
\text { institutions) }\end{array}$ & $\begin{array}{c}\% \text { of U.S. Students } \\
\text { Who Engaged in the } \\
\text { Behavior at Least } \\
\text { Once in High School } \\
\text { (2,537 first year } \\
\text { students from } 5 \\
\text { institutions) }\end{array}$ \\
\hline \multicolumn{3}{|c|}{ Cheating on a Test or Exam } \\
\hline Getting Q/A from someone who has taken test & 30 & 59 \\
\hline $\begin{array}{l}\text { Copying from another student during test WITH her or } \\
\text { her knowledge }\end{array}$ & 8 & 23 \\
\hline $\begin{array}{l}\text { Copying from another student during a test } \\
\text { WITHOUT his or her knowledge }\end{array}$ & 11 & 24 \\
\hline Using unpermitted crib notes during a test & 8 & 20 \\
\hline $\begin{array}{l}\text { Using an unauthorized electronic device (e.g., cell } \\
\text { phone) to cheat during an exam }\end{array}$ & 5 & 8 \\
\hline Helping someone else cheat on a test & 10 & 32 \\
\hline Cheating on a test in any other way & 9 & 25 \\
\hline \multicolumn{3}{|c|}{ Cheating on Homework Assignments } \\
\hline $\begin{array}{l}\text { Working on an assignment with others when the } \\
\text { instructor asked for individual work }\end{array}$ & 44 & 73 \\
\hline Receiving unpermitted help on an assignment & 26 & 46 \\
\hline Turning in work done by someone else & 5 & 11 \\
\hline
\end{tabular}




\begin{tabular}{|c|c|c|}
\hline $\begin{array}{l}\text { In a course requiring computer work, copying a } \\
\text { friend's program rather than doing your own }\end{array}$ & 10 & 9 \\
\hline $\begin{array}{l}\text { Using false or forged excuse to obtain extension on } \\
\text { due date or to delay writing an exam }\end{array}$ & 16 & 25 \\
\hline \multicolumn{3}{|c|}{ Plagiarism on Papers } \\
\hline $\begin{array}{l}\text { Copying a few sentences of material from a written } \\
\text { source without [citing] them }\end{array}$ & 36 & 49 \\
\hline $\begin{array}{l}\text { Copying a few sentences from an internet source } \\
\text { without [citing] them }\end{array}$ & 37 & 48 \\
\hline Fabricating or falsifying a bibliography & 11 & 26 \\
\hline $\begin{array}{l}\text { Copying material almost word for word from a written } \\
\text { source and turning it in as your own work }\end{array}$ & 6 & 10 \\
\hline Turning in a paper copied from another student & 7 & 13 \\
\hline $\begin{array}{l}\text { Turning in a paper obtained in large part from a paper } \\
\text { "mill" or website }\end{array}$ & 3 & 5 \\
\hline \multicolumn{3}{|l|}{$\begin{array}{ll} & \text { Falsifying Data } \\
\end{array}$} \\
\hline Fabricating or falsifying lab data & 16 & 41 \\
\hline Fabricating or falsifying research data & 7 & 17 \\
\hline
\end{tabular}

The McCabe journal article ${ }^{5}$ included survey data taken in 1995-1996 from 1,164 respondents at schools with no honor code and 782 respondents at schools with honor codes. Summary indicators of cheating were used and these results are reposted and abbreviated to only engineering students in Table 2. Additionally, a second table with specific indicators of cheating was used and these results are reposted similarly in Table 3.

Table 2: Summary Cheating Indicators by Engineering Students ${ }^{5}$

\begin{tabular}{|l|c|c|}
\hline \multicolumn{1}{|c|}{ Summary Cheating Indicators } & $\begin{array}{c}\text { \% Engineering Students at } \\
\text { Schools with No Honor Code } \\
\text { (N=255) }\end{array}$ & $\begin{array}{c}\text { \% Engineering Students at } \\
\text { Schools With Honor Code } \\
(\mathrm{N}=139)\end{array}$ \\
\hline Serious & Examination Cheating \\
\hline Repetitive & 51 & 21 \\
\hline All & 23 & 5 \\
\hline \multicolumn{3}{|c|}{ Written Cheating } \\
\hline Serious & 70 & 29 \\
\hline Repetitive & 27 & 50 \\
\hline All & 82 & 61 \\
\hline \multicolumn{2}{|c|}{} \\
\hline All Serious Cheating & 81 & 56 \\
\hline Total Cheating & 90 & 68 \\
\hline
\end{tabular}

Table 3: Engineering Students Admitting to Various Forms of Cheating ${ }^{5}$

\begin{tabular}{|l|c|c|}
\hline \multicolumn{1}{|c|}{ Cheating Indicators } & $\begin{array}{c}\text { \% Engineering Students at } \\
\text { Schools with No Honor Code } \\
\text { (N=255) }\end{array}$ & $\begin{array}{c}\text { \% Engineering Students at } \\
\text { Schools With Honor Code } \\
\text { (N=139) }\end{array}$ \\
\hline $\begin{array}{l}\text { Copied on exam without other's } \\
\text { knowledge }\end{array}$ & Serious Exam Cheating & 14 \\
\hline Copied on exam with other's & 30 & 3 \\
\hline
\end{tabular}




\begin{tabular}{|l|c|c|}
\hline knowledge & \multicolumn{1}{|c|}{27} & \multicolumn{1}{|c|}{} \\
\hline Used crib notes & \multicolumn{1}{|c|}{27} & 4 \\
\hline Helped other cheat on exam & \multicolumn{1}{|c|}{ Serious Cheating on Written Work } \\
\hline \multicolumn{1}{|c|}{27} & 23 \\
\hline $\begin{array}{l}\text { Turned in copied material as own } \\
\text { work }\end{array}$ & 28 & 15 \\
\hline Fabricated/falsified bibliography & 24 & 11 \\
\hline $\begin{array}{l}\text { Turned in work done by someone } \\
\text { else }\end{array}$ & 48 & 34 \\
\hline $\begin{array}{l}\text { Copied a few sentences without } \\
\text { [citing] }\end{array}$ & Other & 31 \\
\hline & 62 & 17 \\
\hline $\begin{array}{l}\text { Worked on assignment with } \\
\text { others when instructor wanted } \\
\text { individual work }\end{array}$ & 52 & 39 \\
\hline $\begin{array}{l}\text { Copied another's computer } \\
\text { program }\end{array}$ & 64 & \\
\hline Falsified lab data & \multicolumn{1}{|c|}{} \\
\hline
\end{tabular}

\section{Results and Discussion}

The survey data taken from the student responses at each institution were sorted by frequency of response for each population, and percentages were calculated. The results per institution for the first 8 survey questions (asked of all institutions polled) are available in Table E1 in Appendix E. For further data analysis, each question and type of response was also coded and evaluated. For example, question 1 asks if students believe people are behaving less ethically, the same, or more ethically in the past 6-10 years. Student responses were then coded into a less $=0$, same $=1$, and more $=2$ format for analysis. Therefore, a score of 1 indicates that students felt that people behaved similarly in the past 6-10 years, where as a score less than 1 indicates students felt people behaved somewhat less ethically and a score of greater than 1 indicates students felt people behaved somewhat more ethically.

The data for the first 5 survey questions for all institutions polled is shown in Figure 1. As illustrated, question 1 results indicate that overall students feel people have become slightly less ethical in the past 6-10 years with an average value of 0.74 . Results were similar between the three schools with no statistical difference in the values. This response is interesting because we didn't specify any particular groups of people, just people in general, and we are not sure what might be driving this response. One possible reason could include an increase of ethics perception due to prevalence in the media or increased awareness due to ethics instruction in the curricula. 
1. In the last 6-10 years, have people in general:

2a. Have you ever done something unethical at WORK that could (or did) have a harmful effect?

2b. Have you ever done something unethical at SCHOOL that could (or did) have a harmful effect?

3a. Do you know of anyone at WORK who has done something you consider unethical?

3b. Do you know of anyone at $\mathrm{SCHOOL}$ who has done something you consider unethical?

4a. Have you ever felt "punished" (lower grade, ostracized by peers, loss of promotion, job loss, no...

4b. Have you ever felt "punished" (lower grade, ostracized by peers, loss of promotion, job loss, no.

5a. Do pressures at WORK (time, grade, profitability) ever cause you to seriously think about doing...

5b. Do pressures at SCHOOL (time, grade, profitability) ever cause you to seriously think about...

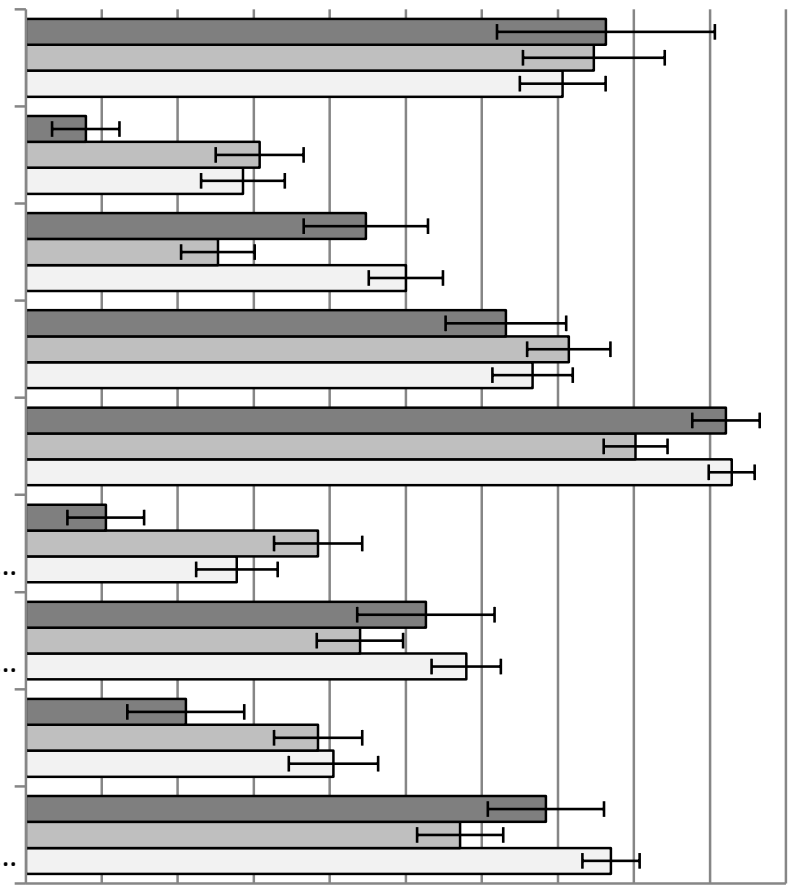

$\begin{array}{lllllllllll}0 & 0.1 & 0.2 & 0.3 & 0.4 & 0.5 & 0.6 & 0.7 & 0.8 & 0.9 & 1\end{array}$ Numeric Value of Student Responses

$\square$ RHIT $\square$ CC $\square$ UND

Figure 1: Student responses after data coding from questions 1 through 5 on the ethics survey

Questions 2 through 5 asked students to relate ethical behaviors relating to activities taking place either at work or at school. A 'No' response was coded as a value of 0 and a 'Yes' response as a value of 1. As shown in Figure 1, the responses for question 2 indicated that student responses relating to work were the statistically similar for UND and CC students with an average value of 0.30 , but that RHIT had a significantly lower value at 0.08 . This is likely due to the limited work experience that the traditional first-year students at RHIT had in comparison to the other student populations at the other institutions. The response results relating to school showed that significantly more students from UND and RHIT had felt they had done something unethical, with values 0.5 and 0.45 respectively, than students from $\mathrm{CC}$ with a value of 0.25 . This is interesting because both UND and RHIT have honor codes, while CC does not; the responses were quite high for the two honor code schools with almost $50 \%$ of students admitting to unethical behavior at school.

Responses from question 3 were statistically similar for all three schools with responses relating to work with an average response between the three schools of 0.67 , indicating a majority of student knew someone at work with behaviors the students felt were unethical. Even more shocking are the school related responses which indicated that the vast majority of students knew someone at school engaging in unethical behavior. UND and RHIT were statistically similar with a value of 0.92 and $\mathrm{CC}$ with a value of 0.80 . These numbers are alarming, but compare with the 
percentage of undergraduate students who report having cheated during college which has remained relatively constant for the past 40 years at around $84 \% .^{4}$

Ethics survey question 4 indicated that students at all the schools felt 'punished' for making ethical choices both at work and at school. Again, students at CC had the highest value (0.38), likely due to the greater work experience by these students, while UND had a slightly smaller value at 0.28 and RHIT had a small value at 0.11 . At school it was interesting to note that the values were much higher than for those at work with all schools reporting values between 0.4 and 0.6. This is interesting as the education system should not be sending the message that making ethical decisions leads to 'punishment' whether in perception or reality. In open-ended student comments regarding the survey, it seems that some students feel that they are earning lower grades from actually doing homework rather than the higher grades that their peers are receiving from copying homework sets from materials such as problem solution manuals. This realization may be an excellent opportunity for schools to educate faculty about this form of cheating and the perceptions they are given to their students.

Student data from question 5 showed that work-related responses are statistically similar for UND and CC with an average value of 0.39 of students feeling pressured to do something unethical, while at RHIT they were somewhat less pressured at work with a value of 0.21 , again likely due to less work experience in the student population. At school, UND students felt the most pressured to be unethical with a value of 0.77 , while students at RHIT were in the middle with a value of 0.68 , and CC students feeling the least pressure with a value of 0.57 . These results are similar to anecdotal evidence from students at these schools with students at the more expensive, private colleges feeling more pressure to succeed than their colleagues at public colleges. These results are also comparative to question 4 where students at the 'higher pressure' schools (UND and RHIT) had higher values for feeling 'punished' regarding ethical behavior at well.

Question 6 on the survey asked students to rate groups both at school and in the work place according to their ethical behaviors with a value of 1 being very ethical, a value of 2 for average ethical behavior and a value of 3 having somewhat unethical behavior. The results of this question are shown below in Figure 2. When asking students which groups at school they feel behave ethically, student responses are statistically similar for all the institutions polled. Students felt that 'students' were the least ethical group with an average value of 2.16 , while the remaining groups of faculty, staff and administration were roughly the same value between 1.5 and 1.6. At work, student responses were somewhat more disparate with all groups averaging lower values (more ethical behaviors) with the exception of the upper management group which CC students felt were the most unethical with a value of 1.86. In general, the CC students responses for business groups were higher than those of the other two institutions again, likely a reflection of a larger work experience than those of their traditional student peers. 


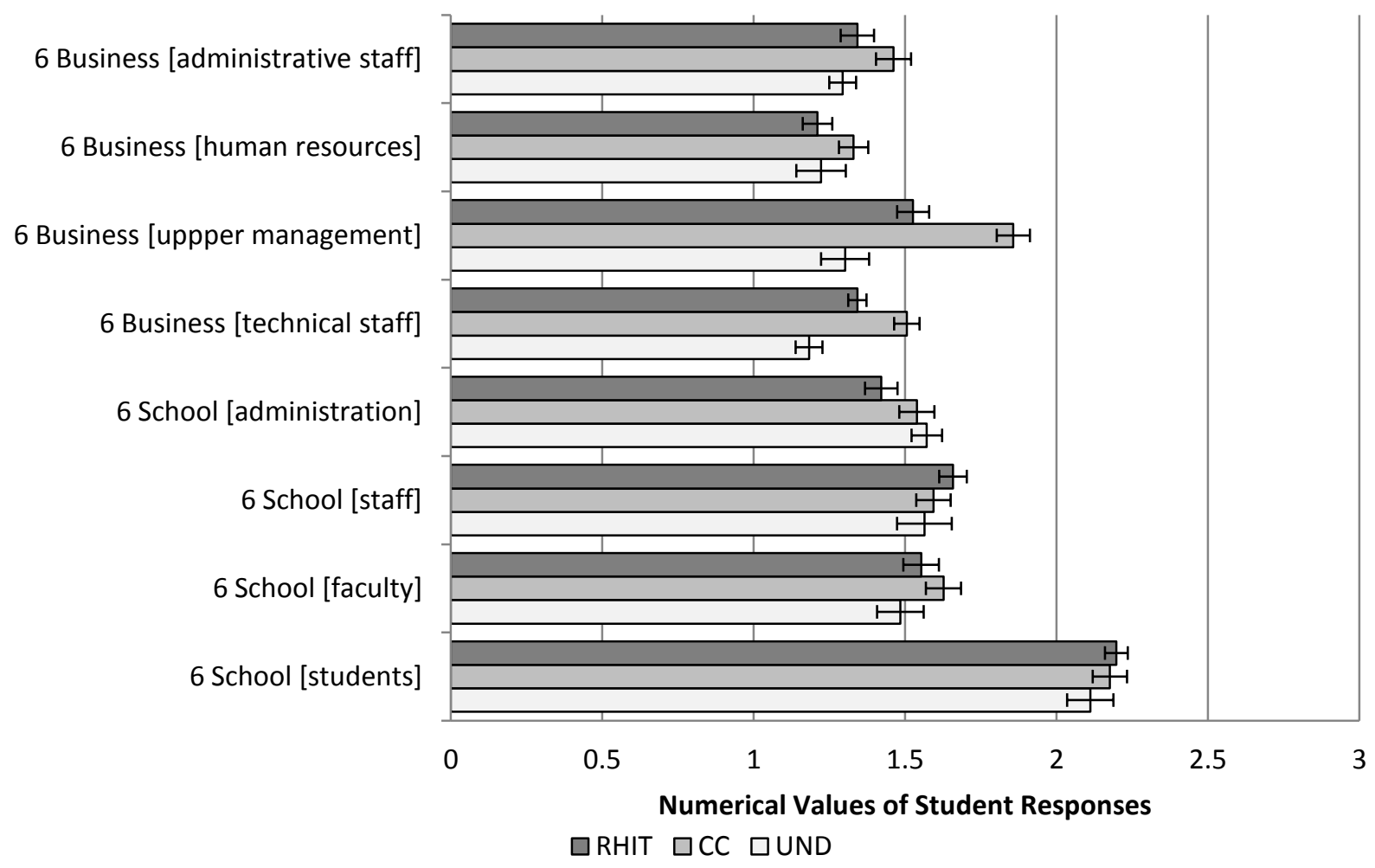

Figure 2: Coded student responses from question 6 on the ethics survey "How would you rate the following groups in your school or workplace on their handling of ethics?"

Questions 7 and 8 on the survey asked students to give a scaled response $(1=$ strongly agree, $2=$ somewhat agree, $3=$ neutral, $4=$ somewhat disagree, 5 strongly disagree) to whether education and business should behave ethically and if ethics and social responsibility were symbiotically related. Responses analyzed for these questions are available in Figure 3. For question 7 , students from UND felt as though ethics were slightly less important in both education and business groups than did the RHIT or CC students, with the average of responses falling in the agreement region of the scale. Values for the education group were 1.93 versus 1.60 and 1.52 , respectively, and for the business group of 2.59 versus 1.79 and 1.73 , respectively. The responses from question 8 were fairly similar with all institutions reporting a general agreement with the statement with values between 1.78 and 2.03 . 
7a. Ethical decision-making is always good for education.

7b. Ethical decision-making is always good for business

8. Social responsibility and ethics are symbiotically related.

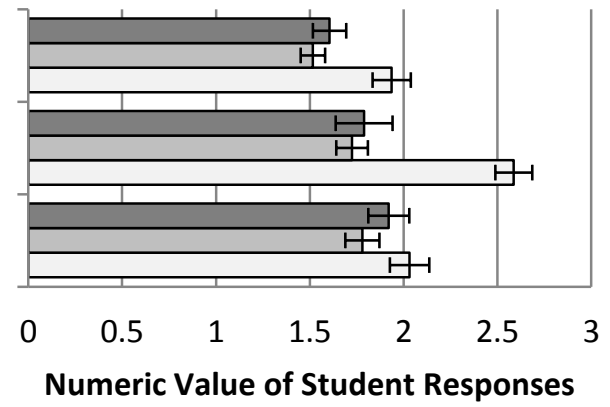

$\square$ RHIT $\square$ CC $\square$ UND

Figure 3: Coded student responses from questions 7 and 8 on the ethics survey

The final question on the ethics survey was only asked only of students from UND and CC. Elements of this question can also be compared to national survey results from $\mathrm{CAI}^{10}$ and McCabe ${ }^{5}$, previously shown in Tables 1-3. Results for this question are presented as percentages for comparison to the literature surveys and are available in Table 4. For each of the specific behaviors polled, conclusions are difficult to draw due to the disparate nature even between the two literature surveys. In this paper, the term 'similar' can be meant as within $\pm 5 \%$ of one or more of the literature surveys.

Table 4: Percentage of students from UND and CC answering Yes to the ethical scenarios presented

\begin{tabular}{|l|c|c|}
\hline \multicolumn{1}{|c|}{ Ethical Scenario } & \multicolumn{1}{|c|}{$\begin{array}{l}\text { \% Students from } \\
\text { Notre Dame (N=126) }\end{array}$} & $\begin{array}{l}\text { \% Students from } \\
\text { Century (N=91) }\end{array}$ \\
\hline 9. Have you ever done the following on one or more occasions during your college career? \\
\hline $\begin{array}{l}\text { a) Gotten test questions or answers from someone who } \\
\text { has already taken the same test before you }\end{array}$ & 18.3 & 14.3 \\
\hline $\begin{array}{l}\text { b) Copied from another student during test WITH } \\
\text { his/her knowledge }\end{array}$ & 4.8 & 12.1 \\
\hline c) Using unpermitted crib notes during a test & 7.1 & 3.3 \\
\hline $\begin{array}{l}\text { d) Using an unauthorized electronic device (e.g., cell } \\
\text { phone) to cheat during an exam }\end{array}$ & 1.6 & \\
\hline e) Helping someone else cheat on a test & 7.9 & 20.9 \\
\hline f) Cheating on a test in any other way & 14.3 & 45.1 \\
\hline $\begin{array}{l}\text { g) Working on an assignment with others when the } \\
\text { instructor asked for individual work }\end{array}$ & 68.3 & 36.3 \\
\hline h) Receiving unpermitted help on an assignment & 48.4 & 38.5 \\
\hline i) Turned in work done by someone else & 15.9 & 2.2 \\
\hline $\begin{array}{l}\text { j) Copied someone else's homework (i.e. problem set) } \\
\text { directly }\end{array}$ & 59.5 & 15.4 \\
\hline $\begin{array}{l}\text { k) In a course requiring computer work, copying a } \\
\text { friend's program rather than doing your own }\end{array}$ & 45.2 & 20.9 \\
\hline 1) Copied a program from the internet without citing it & 12.7 & \\
\hline $\begin{array}{l}\text { m) Using false or forged excuse to obtain extension on } \\
\text { due date or to delay writing an exam }\end{array}$ & 4.8 & \\
\hline
\end{tabular}




\begin{tabular}{|l|c|c|}
\hline $\begin{array}{l}\text { n) Copying a few sentences of material from a written } \\
\text { source without [citing] them }\end{array}$ & 15.1 & 31.9 \\
\hline $\begin{array}{l}\text { o) Copying a few sentences from an internet source } \\
\text { without [citing] them }\end{array}$ & 22.2 & 38.5 \\
\hline p) Fabricating or falsifying a bibliography & 5.6 & 14.3 \\
\hline $\begin{array}{l}\text { q) Copying material almost word for word from a } \\
\text { written source and turning it in as your own work }\end{array}$ & 2.4 & 2.3 \\
\hline r) Turning in a paper copied from another student & 0.8 & 2.2 \\
\hline $\begin{array}{l}\text { s) Turning in a paper obtained in large part from a } \\
\text { paper "mill" or website }\end{array}$ & 0.8 & \\
\hline t) Fabricating or falsifying lab data & 57.1 & \\
\hline u) Fabricating or falsifying research data & 3.2 & \\
\hline
\end{tabular}

The categories a) $-\mathrm{f}$ ) dealt with exam cheating. Comparison between the student responses from UND and CC showed that categories b) - e) were similar to findings from the literature surveys. This means that our students were behaving similarly to students from those studies. It is also noted that the exam cheating values were relatively low in comparison to other cheating behaviors. Differences are noted from the CAI study in category a) where our polled students reported less cheating dealing with obtaining previously taken exam questions, and in category f) where our polled students reported more cheating in other ways not mentioned in other categories. These differences could potentially mean that our students are simply not finding that getting test questions from previous test takers are a useful means of cheating and instead their sources are listed in the 'other' category f) resulting in higher reportings for that category.

The categories g) $-\mathrm{j}$ ) dealt with homework cheating. Student responses revealed similar results to those in the literature surveys in all but category $\mathrm{j}$ ). Both UND and CC students reported higher rates of direct homework set copying than those seen by McCabe. From open-ended comments about cheating included in the student responses, this is likely due to the pressures that students are feeling for high workloads and other intra- or extra-curricular activities. In addition, several comments felt that the homework sets assigned were 'busy work' and not that crucial to student learning. Therefore, the conclusion may be drawn that students do not feel as unethical about copying homework and justify those feelings with their active lives and similar feelings from their peers.

Categories k) - s) dealt with plagiarism in several forms. Plagiarism as it relates to computer programming is seen in categories $\mathrm{k}$ ) and 1). Interestingly, in category $\mathrm{k}$ ) which specifically asks students about copying programs from friends, $\mathrm{CC}$ responses were extremely low in comparison to all literature surveys while UND was high and comparable to the McCabe study from schools with no honor code, although UND does have an honor code. No additional information was available to suggest a reason for these differences. Category 1) had no literature comparison available, but results were similar between the two polled schools in this study.

More typical plagiarism efforts dealing with copying material, falsifying bibliographies, or turning in material that is not their own are included in categories $\mathrm{m}$ ) $-\mathrm{s}$ ). Results from questions in categories p), q), and s) were similar to those in the literature. Categories o), m), and n) were similar to the literature for $\mathrm{CC}$, but results from UND were lower than for the literature institutions. Category r) was the only category for which both UND and CC were lower than for 
the literature survey. After reading through the open-ended student comments, the lower percent of students reporting various plagiarism activities at UND is likely due to the amount of laboratory time spent with research professors. Especially when contrasted with students at CC where formal laboratories are less common (generally not common in most curricula for freshman and sophomore engineering students), it is likely that these students have simply not had as much exposure to many of the issues relating to plagiarism, such as formal report writing.

Finally, categories t) and $\mathrm{u}$ ) dealt with lab and research data falsification or forging. Only UND was polled here, again due to the lower amount of laboratories both for school work and research at CC. These results show that UND was found to have response rates more similar to that of the 'no honor code' schools in McCabe's study as it relates to lab work, and similar to that of CAI for research work.

\section{Conclusions}

Results from this study have shown that students from three different institutions do perceive and act on ethics differently. Results from this study found that high numbers of students, nearly $50 \%$ to over $90 \%$, of students have done, considered and know others who have engaged in unethical behaviors, especially at school. Some similarities can be drawn between the types of institutions, in general relating to the amount of work experience the students have, or the real or perceived pressures relating to private versus public institutions. For example, at CC where more students have significant work experience, students tended to view business groups with somewhat more unethical behaviors than at the other schools where the student populations are more 'traditional'. Another example includes the perceived pressures of private institutions versus public. The student responses from private institutions (higher pressure scenarios) seem to include higher rates of unethical behaviors than those at public institutions (lower pressure scenarios), and students were more apt to try and justify their actions. Finally, a comparison between UND and CC and literature surveys reveals that students polled in this study behave similarly to those in other studies, with a few differences in the areas of exam cheating and plagiarism.

\section{Bibliography}

[1] T. Harding, "Predicting Academic Dishonesty in Engineering College Students," [Online]. Available: http://www.academicintegrity.org/icai/assets/harding.pdf. [Accessed 12 2012].

[2] S. Nonis and C. Swift, "An examination of the relationship between academic dishonesty and workplace dishonesty: A multicampus investigation," Journal of Education for Business, vol. 76, pp. 69-77, 2001.

[3] R. L. Sims, "The relationship between academic dishonesty and unethical busniess practices," Journal of Education for Business, vol. 68, pp. 207-211, 1993.

[4] C. Finelli, T. Harding, D. Carpenter and M. Mayhew, "Academic integrity among engineering undergraduates: Seven years of research by the $\mathrm{E}^{\wedge} 3$ Team," in $A S E E$ Conference Proceedings, Waikiki, 2007. 
[5] D. L. McCabe, "Classroom Cheating Among Natural Science and Engineerig Majors," Science and Engineering Ethics, vol. 3, pp. 433-445, 1997.

[6] W. J. Bowers, Student dishonesty and its control in college, New York: Bureau of Applied Social Research, Columbia University, 1964.

[7] J. Harp and P. Taietz, "Academic itegrity and social structure: A study of cheating among college students," Social Problems, vol. 13, pp. 365-373, 1966.

[8] M. Bouville, "Why is Cheating Wrong?," Studies in Philosophy \& Education, vol. 29, no. 1, pp. 67-76, 2010.

[9] G. Banik, "Ethics: Why is it important and how we can teach it for Engineering and construction students?," in ASEE Conference Proceedings, San Antonio, 2011.

[10] Center for Academic Integrity, "Student Engagement in Academic Dishonesty," 2004. 
Appendices

Appendix A: Ethics survey written and presented at Rose-Hulman Institute of Technology Appendix B: Ethics survey written and presented at the University of Notre Dame Appendix C: Ethics survey written and presented at Century College

Appendix D: Analyzed survey data from student responses at RHIT, UND and CC for questions 1-8 of the ethics survey 


\section{Appendix A: Ethics survey written and presented at Rose-Hulman Institute of Technology}

1. In the last 6-10 years, have people in general:
a. become less ethical?
b. become more ethical?
c. remained the same?

2. Have you ever done something unethical at work or school that could (or did) have a harmful effect?
Work
School
a. Yes
a. Yes
b. No
b. No

3. Do you know of anyone at work or school who has done something you consider unethical?
Work
School
a. Yes
a. Yes
b. No
b. No

4. Have you ever felt "punished" (lower grade, ostracized by peers, loss of promotion, job loss, no pay increase) for making an ethical, but unpopular decision in your workplace or school?

Work

a. Yes
b. No
School

a. Yes

b. No

5. Do pressures at school and/or work (time, grade, profitability) ever cause you to seriously think about doing something you would consider ethically wrong?

\section{Work}

a. Yes

b. No

\section{School}

a. Yes

b. No

6. How would you rate the following groups in your school or workplace on their handling of ethics? $(1=$ very ethical; 2 = average; $3=$ somewhat unethical, NA if not applicable)

\section{School}

students
faculty
staff
administration

\section{Work}

_ technical staff

upper management human resources administrative staff

7. Ethical decision-making is always good for

\section{Education}

a. Strongly agree

b. Somewhat agree

c. Neither agree nor disagree

d. Somewhat disagree

e. Strongly disagree

\section{Business}

a. Strongly agree

b. Somewhat agree

c. Neither agree nor disagree

d. Somewhat disagree

e. Strongly disagree

8. Social responsibility and ethics are symbiotically related
a. Strongly agree
b. Somewhat agree
c. Neither agree nor disagree
d. Somewhat disagree
e. Strongly disagree 
Appendix B: Ethics survey written and presented at the University of Notre Dame

1. What is your class year?
a. First year
b. Second year
c. Third year
d. Fourth year
e. Fifth year

2. What is your major?
a. Aeronautical Engineering
b. Chemical Engineering
c. Civil Engineering
d. Computer Science and Engineering
e. Electrical Engineering
f. Mechanical Engineering
g. Geoscience

3. In the last $6-10$ years, have people in general:
a. become less ethical?
b. become more ethical?
c. remained the same?

4. Have you ever done something unethical at work or school that could (or did) have a harmful effect?
Work
School
a. Yes
a. Yes
b. No
b. No

5. Do you know of anyone at work or school who has done something you consider unethical?

\section{Work}

a. Yes
b. No

\section{School}

a. Yes

b. No

6. Have you ever felt "punished" (lower grade, ostracized by peers, loss of promotion, job loss, no pay increase) for making an ethical, but unpopular decision in your workplace or school?

Work

a. Yes

b. No
School

a. Yes

b. No

7. Do pressures at school and/or work (time, grade, profitability) ever cause you to seriously think about doing something you would consider ethically wrong?

\section{Work}

a. Yes

b. No

\section{School}

a. Yes

b. No 
8. How would you rate the following groups in your school or workplace on their handling of ethics? $(1$ = very ethical; 2 = average; 3 = somewhat unethical, NA if not applicable)

\section{School}

students

faculty

staff

administration
Work

technical staff upper management human resources administrative staff

9. Ethical decision-making is always good for

\section{Education}
a. Strongly agree
b. Somewhat agree
c. Neither agree nor disagree
d. Somewhat disagree
e. Strongly disagree

\section{Business}

a. Strongly agree

b. Somewhat agree

c. Neither agree nor disagree

d. Somewhat disagree

e. Strongly disagree

10. Social responsibility and ethics are symbiotically related
a. Strongly agree
b. Somewhat agree
c. Neither agree nor disagree
d. Somewhat disagree
e. Strongly disagree

Please indicate if you have done the following on one or more occasions during your undergraduate college career.

\begin{tabular}{|l|l|l|}
\hline Survey Question & $\begin{array}{l}\text { Yes, I have } \\
\text { done this one or } \\
\text { more times } \\
\text { during my } \\
\text { college career. }\end{array}$ & $\begin{array}{l}\text { No, I have never } \\
\text { done this during } \\
\text { my college } \\
\text { career. }\end{array}$ \\
\hline Test & Yes & No \\
\hline $\begin{array}{l}\text { Gotten test questions or answers from someone who has } \\
\text { already taken the same test before you }\end{array}$ & Yes & No \\
\hline $\begin{array}{l}\text { Copied from another student during a test with his or her } \\
\text { knowledge }\end{array}$ & Yes & No \\
\hline Used unpermitted crib notes during a test & Yes & No \\
\hline $\begin{array}{l}\text { Use an unauthorized electronic device (such as a cell } \\
\text { phone) to cheat during an exam }\end{array}$ & Yes & No \\
\hline Helped someone else cheat on a test & Yes & No \\
\hline Cheated on a test in any other way & Yes & No \\
\hline Homework & & No \\
\hline $\begin{array}{l}\text { Worked on an assignment with others when the instructor } \\
\text { asked for individual work }\end{array}$ & Yes & No \\
\hline Received unpermitted help on an assignment & Yes & Yes \\
\hline Turned in work done by someone else & &
\end{tabular}




\begin{tabular}{|l|l|l|}
\hline Copied someone else's homework directly & Yes & No \\
\hline $\begin{array}{l}\text { (In a course requiring computer work) Copied another } \\
\text { student's program rather than doing your own }\end{array}$ & Yes & No \\
\hline $\begin{array}{l}\text { (In a course requiring computer work) Copied a program } \\
\text { from the Internet without citing it }\end{array}$ & Yes & No \\
\hline $\begin{array}{l}\text { Used a false or forged excuse to obtain an extension on due } \\
\text { dates or to delay taking an exam }\end{array}$ & Yes & No \\
\hline Papers & & No \\
\hline $\begin{array}{l}\text { Copied a few sentences of material from a written source } \\
\text { without footnoting them in a paper }\end{array}$ & Yes & No \\
\hline $\begin{array}{l}\text { Copied a few sentences of material from an Internet source } \\
\text { without footnoting them in a paper }\end{array}$ & Yes & No \\
\hline Fabricated or falsified a bibliography & Yes \\
\hline $\begin{array}{l}\text { Copied material almost word for word from a written } \\
\text { source and turned it in as your own work }\end{array}$ & Yes & No \\
\hline Turned in a paper copied from another student & Yes & No \\
\hline $\begin{array}{l}\text { Turned in a paper obtained in large part from a term paper } \\
\text { "mill" or website }\end{array}$ & Yes & No \\
\hline Data collection/analysis & Nes & No \\
\hline Fabricated, falsified, or otherwise misrepresented lab data & Yes & Yabricated, falsified, or otherwise misrepresented research \\
data & Yes & \\
\hline
\end{tabular}


Appendix C: Ethics surveys written and delivered to students at Century College

1. In the last 6-10 years, have people in general:
a. become less ethical?
b. become more ethical?
c. remained the same?

2. Have you ever done something unethical at work or school that could (or did) have a harmful effect?
i. Work
School
ii. a. Yes
a. Yes
iii. b. No
b. No

3. Do you know of anyone at work or school who has done something you consider unethical?
i. Work
School
ii. a. Yes
a. Yes
iii. b. No
b. No

4. Have you ever felt "punished" (lower grade, ostracized by peers, loss of promotion, job loss, no pay increase) for making an ethical, but unpopular decision in your workplace or school?
i. Work
School
ii. a. Yes
a. Yes
iii. b. No
b. No

5. Do pressures at school and/or work (time, grade, profitability) ever cause you to seriously think about doing something you would consider ethically wrong?
i. Work
School
ii. a. Yes
a. Yes
iii. b. No
b. No

6. How would you rate the following groups in your school or workplace on their handling of ethics? $(1=$ very ethical; $2=$ average; $3=$ unethical, NA if not applicable $)$
School
a.
b.
c.
d. students faculty staff administration

Work technical staff upper management human resources administrative staff

7. Ethical decision-making is always good for

\section{Education}

a. Strongly agree

b. Somewhat agree

c. Neither agree nor disagree

d. Somewhat disagree

e. Strongly disagree

\section{Business}

a. Strongly agree

b. Somewhat agree

c. Neither agree nor disagree

d. Somewhat disagree

e. Strongly disagree 
8. Social responsibility and ethics are symbiotically related
a. Strongly agree
b. Somewhat agree
c. Neither agree nor disagree
d. Somewhat disagree
e. Strongly disagree

9. Please indicate if you have done the following on one or more occasions during your college career.

$\mathrm{N}=\mathrm{No}$, I have never done this during my college career

$\mathrm{Y}=\mathrm{Yes}, \mathrm{I}$ have done this one or more times during my college career

a. Gotten test questions or answers from someone who has already taken the same test before you

b. Copied from another student during a test WITH his or her knowledge

c. Used unpermitted crib notes during a test

d. Cheated on a test in any other way

e. Worked on an assignment with others when the instructor asked for individual work

f. Received unpermitted help on an assignment

g. Turned in work done by someone else

h. Copied someone else's homework (e.g. problem set) directly

i. (In a course requiring computer work) Copied another student's program rather than doing your own

j. (In a course requiring computer work) Copied a program from the Internet without citing it

$k$. Used a false or forged excuse to obtain an extension on due dates or to delay taking an exam

1. Copied a few sentences of material from a written source without citing them in a paper

m. Copied a few sentences of material from an Internet source without citing them in a paper

n. Fabricated or falsified a bibliography

o. Copied material almost word for word from a written source and turned it in as your own work

p. Turned in a paper copied from another student

q. Turned in a paper obtained in large part from a term paper "mill" or website 
Appendix D: Analyzed survey data from student responses at RHIT, UND and CC for questions 1-8 of the ethics survey

Table D1: Percentage of student responses per institution from RHIT, UND and CC from the first 8 questions on the ethics survey

\begin{tabular}{|l|l|l|l|}
\hline Survey Question & $\begin{array}{l}\text { \% Students } \\
\text { from Rose- } \\
\text { Hulman } \\
(\mathrm{N}=38)\end{array}$ & $\begin{array}{l}\% \text { Students } \\
\text { from Notre } \\
\text { Dame } \\
(\mathrm{N}=126)\end{array}$ & $\begin{array}{l}\% \text { Students } \\
\text { from Century } \\
(\mathrm{N}=91)\end{array}$ \\
\hline
\end{tabular}

1. In the last 6-10 years, have people in general: become less ethical, more ethical, or remained the same

\begin{tabular}{|r|c|c|c|}
\hline Less ethical & 47.4 & 38.9 & 47.3 \\
\hline More ethical & 13.2 & 9.5 & 6.6 \\
\hline Same ethical & 34.2 & 51.6 & 38.5 \\
\hline
\end{tabular}

2. Have you ever done something unethical at work or school that could (or did) have a harmful effect?

\begin{tabular}{|r|c|c|c|}
\hline Work - Yes & 7.9 & 11.1 & 22.0 \\
\hline Work - No & 92.1 & 80.2 & 73.6 \\
\hline School - Yes & 44.7 & 45.2 & 23.1 \\
\hline School - No & 55.3 & 52.4 & 75.8 \\
\hline
\end{tabular}

3. Do you know of anyone at work or school who has done something you consider unethical?

\begin{tabular}{|r|c|c|c|}
\hline Work - Yes & 63.2 & 54.0 & 64.8 \\
\hline Work - No & 36.8 & 39.7 & 31.9 \\
\hline School - Yes & 92.1 & 88.1 & 80.2 \\
\hline School - No & 7.9 & 9.5 & 19.8 \\
\hline
\end{tabular}

4. Have you ever felt "punished" (lower grade, ostracized by peers, loss of promotion, job loss, no pay increase) for making an ethical, but unpopular decision in your workplace or school?

\begin{tabular}{|r|c|c|c|}
\hline Work - Yes & 10.5 & 11.9 & 31.9 \\
\hline Work - No & 89.5 & 80.2 & 64.8 \\
\hline School - Yes & 47.4 & 56.3 & 39.6 \\
\hline School - No & 50.0 & 42.9 & 58.2 \\
\hline
\end{tabular}

5. Do pressures at school and/or work (time, grade, profitability) ever cause you to seriously think about doing something you would consider ethically wrong?

\begin{tabular}{|r|c|c|c|}
\hline Work - Yes & 15.8 & 21.4 & 31.9 \\
\hline Work - No & 81.6 & 69.0 & 64.8 \\
\hline School - Yes & 68.4 & 77.0 & 52.7 \\
\hline School - No & 31.6 & 23.0 & 45.1 \\
\hline
\end{tabular}

6. How would you rate the following groups in your school or workplace on their handling of ethics? $(1=$ very ethical; 2 = average; $3=$ somewhat unethical, NA if not applicable)

School

\begin{tabular}{|r|c|c|c|}
\hline Students & 2.21 & 2.11 & 2.22 \\
\hline Faculty & 1.55 & 1.50 & 1.66 \\
\hline Staff & 1.66 & 1.64 & 1.67 \\
\hline Work Administration & 1.44 & 1.68 & 1.65 \\
\hline
\end{tabular}




\begin{tabular}{|c|c|c|c|}
\hline Technical staff & 1.8 & 1.67 & 1.88 \\
\hline Upper management & 1.83 & 1.67 & 2.14 \\
\hline Human resources & 1.63 & 1.73 & 1.73 \\
\hline Administrative staff & 1.69 & 1.73 & 1.80 \\
\hline \multicolumn{4}{|l|}{ 7. Ethical decision-making is always good for } \\
\hline \multicolumn{4}{|l|}{ Education } \\
\hline Strongly agree & 42.1 & 42.9 & 54.9 \\
\hline Agree & 55.3 & 32.5 & 38.5 \\
\hline Neutral & 2.6 & 10.3 & 6.6 \\
\hline Disagree & 0.0 & 8.7 & 0.0 \\
\hline Strongly disagree & 0.0 & 4.0 & 0.0 \\
\hline \multicolumn{4}{|l|}{ Business } \\
\hline Strongly agree & 42.1 & 15.1 & 45.1 \\
\hline Agree & 34.2 & 39.7 & 41.8 \\
\hline Neutral & 15.8 & 21.4 & 8.8 \\
\hline Disagree & 5.3 & 19.0 & 4.4 \\
\hline Strongly disagree & 0.0 & 4.8 & 0.0 \\
\hline \multicolumn{4}{|l|}{ 8. Social responsibility and ethics are symbiotically related } \\
\hline Strongly agree & 23.7 & 42.9 & 40.7 \\
\hline Agree & 63.2 & 31.0 & 44.0 \\
\hline Neutral & 10.5 & 11.1 & 7.7 \\
\hline Disagree & 2.6 & 10.3 & 6.6 \\
\hline Strongly disagree & 0.0 & 4.8 & 0.0 \\
\hline
\end{tabular}

